\title{
A STUDY ON CUSTOMERS PREFERENCE AND SATISFACTION LEVEL WITH SPECIAL REFERENCE TO PANTALOONS, PUNE
}

\author{
Ms. Swarali Keshav Dhawale, \\ Student, MITWPU, \\ School Of Management, Kothrud, Pune, Maharashtra
}

\begin{abstract}
Pantaloons is India's leading fashion and lifestyle destination for men, women, children. The friendly and welcoming store staff coupled with fresh, vibrant and stylish merchandise make it a fashion hotspot that shoppers across India flock to. From contemporary ethnic's wear to stylish western wear, from cool casuals to smart formals, from bubbly kids wear to cute infant wear, Pantaloons has it all. In addition to fashionable and trendy apparel, it has range of handbags, footwear and accessories that make pantaloons one stop style destination. The research involved gathering wide information about company, its products, consumer preference and satisfaction level towards Pantaloons. From the information collected, various aspects were identified where the company needs to focus on customers preference and satisfaction level of pantaloons to increase sales. The research was conducted through primary and secondary data. Secondary data was collected through visiting various websites, and other reliable sources. Primary data was collected through a well framed questionnaire, of which later a detailed analysis was done using various statistical I.T tools MS Word and MS Excel. On the basis, the secondary data analysis and the extensive analysis of the primary data, interpretation were drawn for the questions and conclusion is drawn. Certain suggestions are also drawn from the analysis to help.
\end{abstract}

Key words: VIR virtual trial room, IT- information technology, Fashion and Retail, Simulation, Customer Preferences and Satisfaction level, mn sq.ft- mega newton square feet, APMC Act - agriculture products market committee, F.Y - final year, Ms Microsoft.

\section{INTRODUCTION AND RATIONALE}

Pantaloons is India's Favourite Fast Fashion Destination. It is one of the fastest growing lifestyle apparel retail destination in India constantly innovating designs, concepts and products by infusing the latest trends in fashion and clothing style. A chain of stores for every Indian, pantaloons has a repertoire of lifestyle brand to cater to every customer need across multiple occasions.

Consumer preferences is used primarily to mean to select an option that has the greatest anticipated value among several options by the consumer in order to satisfy his/her needs or desires. Preferences indicate choices among neutral or more valued options available. The preference of the consumer is the result of their behaviour they show during searching, purchasing and disposing the products. Every human being is a consumer of different produces. If there is no consumer, there is no business. Therefore, consumer satisfaction is very important to every businessperson. The consumer satisfaction after purchase depends on the product performance in relation to his/her expectations. Philip Kotler (2008) observed that satisfaction is a person's feelings of pressure or disappointment resulting from product's perceived performance (outcome) in relation to his or her expectations. Consumer satisfaction is the level of a person's felt state resulting from comparing a product's perceived performance (outcome) in relation to the person's expectations. This satisfaction level is a function of difference between perceived performance and expectations. If the product's performance exceeds expectation, the customer is highly satisfied or delighted. If the performance matches the expectations, the customer is satisfied. If the products performance falls short of expectations, the customer is dissatisfied. Consumer satisfaction or dissatisfaction is the feeling derived by the consumer when he compares the product's actual performance with the performance that he expects out of it. Consumers make their expectations from the service quality, service, delivery, communications, past experiences and references. These all are to be judged correctly by the management so that their perceptions match with consumer 


\section{International Journal of Engineering Applied Sciences and Technology, 2020 Vol. 5, Issue 4, ISSN No. 2455-2143, Pages 178-185 \\ Published Online August 2020 in IJEAST (http://www.ijeast.com)}

expectations. If any of these factors are wrongly interpreted, then the expected level of consumer satisfaction cannot be reached.

As we scroll through social media we can see there's no lack of sweats sets or comfortable clothes to do things at this point, no one really knows how or when the pandemic will end ant the fashion industry, just like other industries or business sectors, is scrambling to make it through. One thing is certain that everyone has changed their daily life and also their fashion choices. Also, we can say it has proven major historical events, including pandemic, recessions and wars has changed the way women/men dress.

Clearly COVID-19 substantially effect on the way we dress, many people, celebrities are wearing oversized hoodies and scarfs that covers their faces, big comfortable jeans, we can assume that our fashion might continue to focus on comfortable staples even after the pandemic ends. A fashion historian Raissa bretana who teaches at fashion institute of technology and Pratt institute says that somehow contemporary fashion will continue on its current trajectory of increasing casualness, after this prolonged period of comfortable clothing while in quarantine as we are going to live with COVID-19 for while there will be rise in fashionable masks and hand gloves. In India face mask were already popular with people wearing them day to day basis for reasons ranging protection against pollution and allergies therefore designers can use their skills to create fashionable masks and gloves which are well suited with various categories/types dress with reusable fabric i.e. match the mask with print or colours of the dress/clothes.

\section{OBJECTIVES}

1. To study the customer satisfaction level towards Pantaloons.

2. To study consumer preference towards Pantaloons.

\section{SCOPE}

Pantaloons achieved increased sales over the past years. Due to the prevailing heavy competition in the market, an effort has been made to survey the customer level of satisfaction for Pantaloons. A study with consistency required to comprehend the level of consumer preference and satisfaction level. The survey depends on the preference and satisfaction of the respondents. In today's world rapidly changing technology customer's taste and preference are also characterized by rapid changes. To meet this challenging environment, a firm must be constantly innovating needs and wants. Customers taste and preference provides invaluable items and guidelines for new technologies. Keeping in mind the conveniences of the customer's, the company offer facilities, which in turn bring the customers to their doorsteps. Based on the customer response, suitable modifications can be carried out to increase the Market share as well as companies retail shop profit.

\section{REVIEW OF LITERATURE}

The references for the literature review used for the problem in hand are as follows:

Fabian Herweg, Antonio Rosato (2019), the study analyse a model of price competition and bait-switch strategy where the customers are first to baited by merchants advertising of products or services at low price but upon visiting are pressured by salesperson to consider similar but expensive items (switching). The study proposed baseline model to explain the equilibrium of pricing game. To highlight the key intuition behind result they enrich the baseline model by considering a contracting problem with moral hazard. The result of study the retailers obtained more than competitive profits.

Viktorija viciunaite, Frode Alfnes (2020) examined sustainable business models with a consumer preference perspective. Online survey was conducted with sample of 394 active knitters in Norway

2018. The findings suggested heterogeneous preferences for suitable attributes. The study concluded that firms could increase sustainable consumption through making purchase of sustainable items.

Byoungho Ellie Jin, Daeun chloe shin (2020), The study analyses three areas of disruptive business model innovation in the fashion retail industry. The study further explains the models keenly answer fundamental needs unmet by current business models, the findings suggested the study received limited attention therefore it is concluded that inclusion of cases involving other countries would deepen the understanding of the trends. The study recommends that more research to be done on other industries that face different fundamental challenges.

Hanna Lee, Yingjiao Xu (2019), The study discuss response to growing demand towards enhanced shopping experience through incorporating visual fitting rooms into fashion retail environment. The purpose of study is to conduct a classification of available virtual fitting rooms technologies from the 


\section{International Journal of Engineering Applied Sciences and Technology, 2020 Vol. 5, Issue 4, ISSN No. 2455-2143, Pages 178-185 \\ Published Online August 2020 in IJEAST (http://www.ijeast.com)}

perspective of consumer experience. The finding suggested number of limitations. First, due to high accuracy, attractiveness and interactivity might not fully ensure the most optimised consumer experience. Second, the classification was based on 29 virtual fitting rooms solutions identified through the data collection process.

\section{RESEARCH METHODOLOGY}

The present research work is limited to study the consumer preferences and satisfaction towards Pantaloons in Pune city, Maharashtra. The research process consists of stages or steps that guide the project from its conception through the final analysis, recommendations and ultimate action. The research is based on primary and secondary data collection methods and the research type is descriptive. A structured questionnaire will be designed to gather information for primary data and, for secondary data internet, books and websites.

\section{Statement of problem}

In today's competitive world, consumers play an important role in every business. The main purpose of every business is to know what customers preference is and satisfy its existing customers and attract a new customer which is also known acquiring customers.

\section{Research Hypothesis}

1. There is less significant difference in consumer preference towards online shopping mode.

2. There is significant difference in consumer preference towards virtual trial rooms.

3. There is no association between gender of consumer and the factors of purchase decision.

4. There is no association between age of the consumer and product of purchase.

5. There is significant difference towards consumer preference towards patterns.

6. There is significant difference towards consumer preference towards colour.

7. There is significant difference in satisfaction levels towards pantaloons products.

8. There is significant difference in satisfaction levels towards pantaloons customers service.

\section{Research design}

The research design is intended to provide an appropriate framework for a study. A very significant decision in research design process is the choice to be made regarding research approach since it determines how relevant information for a study will be obtained; however, the research design process involves many interrelated decisions.

This study employed a mixed type of methods. The study consisted of a series of well-structured questionnaire. Hence, this study employs a descriptive research design to agree on the effects of customer preference and satisfaction level, at Pantaloons. descriptive research portrays an accurate profile of persons, events, or situations. This design offers to the researchers a profile of described relevant aspects of the phenomena of interest from an individual, organizational, and industry-oriented perspective. Therefore, this research design enabled the researchers to gather data from a wide range of respondents on the customer preference and satisfaction level in Pune. And this helped in analysing the response obtained.

\section{Research tools}

- Simple percentage analysis

- T-test

\section{Type of research}

Descriptive research has been undertaken in this research work to make research effective and find the results of research working successfully.

\section{$\underline{\text { Population and sample size }}$}

The study of population consists of people in Pune city. A total of 100 sample size responded to questionnaire survey, random sample size was used. The determination of the sample size was adopted from Daniel and Cochran formula. The formula used was for unknown population size Eq. (1) and is given as $\mathrm{E} 1$ where $\mathrm{n}=$ sample size, $\mathrm{Z}=$ statistic for a level of confidence, $\mathrm{P}=$ expected prevalence or proportion (in proportion of one; if $50 \%, \mathrm{P}=0.5$ ), and $\mathrm{d}=$ precision (in proportion of one; if $6 \%, \mathrm{~d}=0.06$ ). $\mathrm{Z}$ statistic (Z): for the level of confidence of $95 \%$, which is conventional, Zvalue is 1.96. In this study, investigators present their results with $95 \%$ confidence intervals (CI).

The expected sample number was 189 at the marginal error of $6 \%$ for $95 \%$ confidence interval of manufacturing industries. However, the collected data indicated that only 100 populations were used for the analysis after rejecting some data having me missing values in the responses from the respondents Hence, the actual data collection resulted in $71 \%$ response rate. The 189 population were assumed to be satisfactory and representative for the data analysis.

\section{$\underline{\text { Sample size }}$}




\section{International Journal of Engineering Applied Sciences and Technology, 2020 \\ Vol. 5, Issue 4, ISSN No. 2455-2143, Pages 178-185 \\ Published Online August 2020 in IJEAST (http://www.ijeast.com)}

The data collection was done with 100 respondents.

\section{$\underline{\text { Sample frame }}$}

The sample frame was collected randomly from the population.

\section{Sample elements}

1. The sample is the representative of all the characters of universe.

2. All units of sample are independent of each other.

3. The number of items in the sample is adequate.

\section{Sample techniques}

Convenience sampling techniques is used in this study.

\section{Data types}

Two types of data were collected that is- Primary data and Secondary data. Primary data was collected through questionnaire and secondary data was collected through external sources.

\section{Data collection and method}

Data collection took place with the help of filling the questionnaire. The questionnaire method has come to the more widely used and economical means of data collections. I found essential to make sure the questionnaire was easy to read and understand to all the spectrum of the people in the sample. It was also important as a researcher to respect the samples time and energy. Hence, the questionnaire was designed in such a way, that its administration would not exceed 45 minutes.

\section{DATA ANALYSIS AND INTERPRETATION}

H1. There is less significant difference in consumer preference towards online shopping mode.

\begin{tabular}{|l|l|}
\hline $\mathrm{N}$ & 2 \\
\hline Mean & 50.000 \\
\hline Std. Deviation & 5.657 \\
\hline Std. Err mean & 4.000 \\
\hline $\mathrm{df}$ & 1 \\
\hline $\mathrm{t}$ & 6.250 \\
\hline Mean difference & 25.000 \\
\hline
\end{tabular}

\section{Critical t}

\begin{tabular}{|l|l|}
\hline \hline One tailed & 6.314 \\
\hline Two tailed & 12.706 \\
\hline
\end{tabular}

Interpretation: above table shows T-test significant at 0.5 level. Since the hypothesis has is accepted there is less significant difference in consumer preference towards online shopping mode.

H2. There is significant difference in consumer preference towards virtual trial rooms.

\begin{tabular}{|l|l|}
\hline $\mathrm{N}$ & 2 \\
\hline Mean & 50.000 \\
\hline Std. Deviation & 50.912 \\
\hline Std. Err mean & 36.000 \\
\hline Df & 1 \\
\hline T & 0.694 \\
\hline Mean difference & 25.000 \\
\hline
\end{tabular}

$\underline{\text { Critical t }}$

\begin{tabular}{|l|l|}
\hline One tailed & 6.314 \\
\hline Two tailed & 12.706 \\
\hline
\end{tabular}

Interpretation: above table shows $\mathrm{T}$-test significant at 0.5 level. Since the hypothesis has is accepted there is significant difference in consumer preference towards virtual trial rooms.

H3. There is no association between gender of consumer and the factors of purchase decision.

\begin{tabular}{|l|l|}
\hline $\mathrm{N}$ & 4 \\
\hline Mean & 25.000 \\
\hline Std. Deviation & 5.099 \\
\hline Std. Err mean & 2.550 \\
\hline Df & 3 \\
\hline T & 0.000 \\
\hline Mean difference & 0.000 \\
\hline
\end{tabular}

$\underline{\text { Critical } t}$

\begin{tabular}{|l|l|}
\hline One tailed & 2.353 \\
\hline Two tailed & 3.182 \\
\hline
\end{tabular}

Interpretation: above table shows T-test significant at 0.5 level. Since the hypothesis has is accepted there is no association between Gender of consumer and the factors of purchase decision.

H4. There is no association between age of the consumer and product of purchase. 
International Journal of Engineering Applied Sciences and Technology, 2020

Vol. 5, Issue 4, ISSN No. 2455-2143, Pages 178-185

Published Online August 2020 in IJEAST (http://www.ijeast.com)

\begin{tabular}{|l|l|}
\hline $\mathrm{N}$ & 4 \\
\hline Mean & 25.000 \\
\hline Std. Deviation & 11.518 \\
\hline Std. Err mean & 5.759 \\
\hline Df & 3 \\
\hline T & 0.000 \\
\hline Mean difference & 0.000 \\
\hline
\end{tabular}

Critical t

\begin{tabular}{|l|l|}
\hline One tailed & 2.353 \\
\hline Two tailed & 3.182 \\
\hline
\end{tabular}

Interpretation: above table shows T-test significant at 0.5 level. Since the hypothesis has is accepted there is no association of age of the consumer and product of purchase.

H5. There is significant difference towards consumer preference towards patterns.

\begin{tabular}{|l|l|}
\hline $\mathrm{N}$ & 5 \\
\hline Mean & 27.246 \\
\hline Std. Deviation & 19.206 \\
\hline Std. Err mean & 8.589 \\
\hline Df & 4 \\
\hline T & 0.261 \\
\hline Mean difference & 0.246 \\
\hline
\end{tabular}

\section{$\underline{\text { Critical t }}$}

\begin{tabular}{|l|l|}
\hline One tailed & 2.132 \\
\hline Two tailed & 2.776 \\
\hline
\end{tabular}

Interpretation: above table shows T-test significant at 0.5 level. Since the hypothesis has is accepted there is significant difference towards consumer preference to patterns.

H6. There is significant difference towards consumer preference towards colour.

\begin{tabular}{|l|l|}
\hline $\mathrm{N}$ & 2 \\
\hline Mean & 50.000 \\
\hline Std. Deviation & 10.479 \\
\hline Std. Err mean & 7.410 \\
\hline Df & 1 \\
\hline
\end{tabular}

\begin{tabular}{|l|l|}
\hline $\mathrm{T}$ & 3.374 \\
\hline Mean difference & 25.000 \\
\hline
\end{tabular}

Critical t

\begin{tabular}{|l|l|}
\hline One tailed & 6.314 \\
\hline Two tailed & 12.706 \\
\hline
\end{tabular}

Interpretation: above table shows $\mathrm{T}$-test significant at 0.5 level. Since the hypothesis has is accepted there is Significant difference towards consumer preference to colours.

H7. There is significant difference in satisfaction levels towards pantaloons products.

\begin{tabular}{|l|l|}
\hline $\mathrm{N}$ & 3 \\
\hline Mean & 33.333 \\
\hline Std. Deviation & 46.586 \\
\hline Std. Err mean & 26.897 \\
\hline Df & 2 \\
\hline T & 0.310 \\
\hline Mean difference & 8.333 \\
\hline
\end{tabular}

Critical t

\begin{tabular}{|l|l|}
\hline One tailed & 2.920 \\
\hline Two tailed & 4.303 \\
\hline
\end{tabular}

Interpretation: above table shows T-test significant at 0.5 level. Since the hypothesis has is accepted there is significant difference in satisfaction levels towards pantaloons products.

H8. There is significant difference in satisfaction levels towards pantaloons customers service.

\begin{tabular}{|l|l|}
\hline $\mathrm{N}$ & 5 \\
\hline Mean & 20.000 \\
\hline Std. Deviation & 22.771 \\
\hline Std. Err mean & 10.183 \\
\hline Df & 4 \\
\hline T & -0.491 \\
\hline Mean difference & -5.000 \\
\hline
\end{tabular}

\section{$\underline{\text { Critical t }}$}

\begin{tabular}{|l|l|}
\hline One tailed & 2.132 \\
\hline Two tailed & 2.776 \\
\hline
\end{tabular}




\section{International Journal of Engineering Applied Sciences and Technology, 2020 Vol. 5, Issue 4, ISSN No. 2455-2143, Pages 178-185 \\ Published Online August 2020 in IJEAST (http://www.ijeast.com)}

Interpretation: above table shows T-test significant at 0.5 level. Since the hypothesis has is accepted there is significant difference in satisfaction level towards customer service.

\section{FINDINGS}

Based on the data gathered the following observations are made:

1. Pantaloons has excellent percentage of customers satisfaction, according to table of analysis.

2. Customer prefer more of online mode of shopping.

3. Most of the consumers are satisfied by pantaloons products.

4. Based on colours preference and patterns most of the consumers preferred bright colours and checks, stripes, and Multiple patterns.

5. Most consumers opted for virtual trial rooms.

6. Most consumers like to buy products of Pantaloons are -Tshirts, shirts, sweatshirts, sweaters And Kurtis, sari's, and other traditional wear.

7. Most consumers want quality attribute in products.

8. More vibrant colours, warm colours of the products are what customers preferred more and Pantaloons can keep one day one colour theme where customers will get all types of products in one preferred colour.

9. Pantaloons can use bargain shopping where it will attract more consumers to buy the products with their own choice of price.

10. As Indian market is price sensitive and our consumer want best quality, Pantaloons must consider the price factor seriously because of COVID-19 consumers are more conscious about where and on what they are spending their money.

11. Pantaloons Does not use virtual reality or simulation technology. 12. Pantaloons doesn't provide customers customization of products.

13. Pantaloons don't have strong social media platform influence. 14. Pantaloons don't have JIT production.

\section{SUGGESTIONS}

1. A simple act of sharing is another thing that is rapidly changing and that is, in return, changing how we dress as stores are closed people are opting for online shopping and we can attract more consumers

2. As we can say many people are opting for online shopping pantaloons can add simulation/simulator so people get attracted and can easily experience store shopping virtually and try out various options of dress and this can increase foot fall of customers 24/7 \{ we can keep customization of dress which can engage customers to spend the

app/website more\}

3. We can encourage people via competition between those who are aspiring to be in fashion industry as a career can participate (registration) and the winner will get his/her design displayed on the shop or app/website with name. We can even keep \#face of pantaloons competition with people wearing pantaloons dress and posing for a photo and excellent photo get to display on app/website and store with the winner name.

4. As we scroll through social media we can see there's no lack of sweats sets or comfortable clothes to do things at this point, no one really knows how or when the pandemic will end ant the fashion industry, just like other industries or business sectors, is scrambling to make it through. One thing is certain that everyone has changed their daily life and their fashion choices. Also, we can say it has proven major historical events, including pandemic, recessions and wars has changed the way women/men dress. Clearly COVID-19 substantially effect on the way we dress, many people, celebrities are wearing oversized hoodies and scarfs that covers their faces, big comfortable jeans, we can assume that our fashion might continue to focus on comfortable staples even after the pandemic ends.

5. A fashion historian Raissa bretana who teaches at fashion institute of technology and Pratt institute says that somehow contemporary fashion will continue on its current trajectory of increasing casualness, after this prolonged period of comfortable clothing while in quarantine as we are going to live with COVID19 for while there will be rise in fashionable masks and hand gloves.

6. In India face mask were already popular with people wearing them day to day basis for reasons ranging protection against pollution and allergies therefore designers can use their skills to create fashionable masks and gloves which are well suited with various categories/types dress with reusable fabric i.e. match the mask with print or colours of the dress/clothes.

7. Bargain shopping: where people can buy clothes on their choice of price \{This can be done to clear stock

8. JIT production 


\section{International Journal of Engineering Applied Sciences and Technology, 2020 \\ Vol. 5, Issue 4, ISSN No. 2455-2143, Pages 178-185 \\ Published Online August 2020 in IJEAST (http://www.ijeast.com)}

9. Dressing from waist up \{can be customized $\}$ So many people working from home and chatting with friends and loved one's on video rather in person, people are opting more dress/clothes from waist up e.g. T-shirts, sweatshirts, tops and etc.

10. Pantaloons can focus on sales of tops or waist up dressing due to work from home situations.

11. More vibrant, natural colours, bright colours to be used and natural comfortable fabric.

12. It is seen that every fashion retail companies use the same indo- western theme, so Pantaloons should come up with unique collections of clothes using various fabrics which can be easily found locally. Following are the best fabrics made in India which can be used by fashion advisors or wardrobe designers of Pantaloons to create new and unique collections of clothes.

Famous for their fabrics-

1. KHADI

2. KALAMKARI-ANDHRA PRADESH

3. BANARASI SILK- VARANASI, UP

4. CHIKANKARI EMBROIDERYLUCKNOW, UP

5. SAMBALPURI FABRIC SAMBALPUR, ODISA

6. IKAT FABRIC - PICHAMPALLI, HYDRABAD

7. CHANDERI- MP

8. PAITHANI

BROCADEAURANGABAD, MAHARASHTRA

9. PATOLQ FABRIC- PATON, GUJRAT

10. PASHMINA- KASHMIR

11. PHULKARI- PUNJAB

12. BANDHANI- GUJRAT ALSO RAJASTHAN

13. KANJIVARAM- KANCHIPURAM, TAMIL NADU

14. MYSORE SILK- MYSURU, KARNATAKA

15. KINNARRI SHAULS- KULLU, HIMACHAL

16. JAMDANI- WEST BENGAL

17. MUGA SILK- ASSAM

18. KASAVU- KERALA

19. MADRAS CHECKS (PLAIDS)CHENNAI, TAMIL NADU

20. BHAGALPURI SILK- BHAGALPUR, BIHAR

21. LEPCHA- SIKKIM

22. KOTA DORIA - KAITHOON VILLAGE, RAJASTHAN

\section{AJRAKH- KUTCH, GUJRAT} AND BARMER, RAJASTHAN

24. NARAYAN PETH SARISOLAPUR, MAHARASHTRA

25. KANTHA-WEST BENGAL

26. KUNBI FABRIC-GOA

27. BAGRU PRINT- RAJASTHAN

28. ILKAL SARI- KARNATAKA 29. MANGALGIRI FABRICVIJAYWADA AND GUNTUR, ANDHRA PRADESH

29. SANGNERI PRINT- RAJASTHAN

30. BOMKAI SARI-GANJAM ODISA

\section{CONCLUSION}

Pantaloons has a very good market share in the Pune city, Maharashtra for fashion segment. The company is offering good services of consumers preference, which is reflected on the customer. Majority of customers are satisfied with the Pantaloons products with better services. Customer prefer more of online mode of shopping. More vibrant colours, warm colours of the products are what customers preferred more and Pantaloons can keep one day one colour theme where customers will get all types of products in one preferred colour. Pantaloons can use bargain shopping where it will attract more consumers to buy the products with their own choice of price. As Indian market is price sensitive and our consumer want best quality, Pantaloons must consider the price factor seriously because of COVID-19 consumers are more conscious about where and on what they are spending their money. Pantaloons can start up with new theme as customers are not going out for physical shopping due pandemic. Pantaloons can start up new themes with various famous fabrics in India which customers usually buy in various festivals, this can gain Pantaloons more increase in sales and customer footfalls around India.

\section{REFERENCES}

- (2019 March 31). Aditya birla fashion Director report.

Business Standard . Retrieved from https://wap.businessstandard.com/compa ny/aditya-birfas40912/annualreport/directorreport

- Aditya Birla Fashion and Retail limited . (). Retrieved from https://m.economicti 
mes.com/adityabirla-fashionandretailltd/stocks/companyid $-\underline{-46091 . \mathrm{cms}}$

- Aditya Birla Fashion and Retail Annual report . (2015). Retrieved from www.abfrl.com

- Aditya Birla Fashion and Retail Annual report . (2016). Retrieved from www.abfrl.com

- Aditya Birla Fashion and Retail Annual report . (2017). Retrieved from www.abfrl.com

- Aditya Birla Fashion and Retail Annual report . (2018). Retrieved from www.abfrl.com

- Aditya Birla Fashion and Retail Annual report . (2019). Retrieved from www.abfrl.com

- Herweg Fabian, \& Rosato Antonio (29 November 2019). Bait and ditch: Consumer naïveté and salesforce incentives. journal of economic \& management strategy , 29. Retrieved from https://onlinelibrary. wiley.com/doi/full/1 0.1111/jems.12336.

- Viciunaite Viktorija, \& Alfnes Frode (1 January 2020). Informing sustainable business models with a consumer preference perspective. journal of cleaner production , 242. Retrieved from https://www.science direct.com/science/a rticle/pii/S09596526 19332871.

- Jin Byoungho Ellie, \& Shin Daeun Cloe (MayJune 2020). Changing the game

to compete: Innovations in the fashion retail industry from the disruptive business model . Business Horizons, 63. Retrieved from https://www.science direct.com/science/a rticle/pii/S0007681320300045.

- $\quad$ H. Lee, \& Y. Xu (1 January 2018).

CONSUMER BEHAVIOR Classification of Virtual Fitting Room (VFR) Technology in the Fashion Industry: From the

Perspective of Customer Experience. International Textile and Apparel Association, 75. Retrieved from https://www.iastated igitalpress.com/itaa/ article/id/1488/.

- 2020, June 19). Aditya birla fashion financial and other reports. Retrieved from http://www.abfrl.com/in vestors/financialandother-reports/ ltd/stocks/companyid-

- Aditya birla fashion 46091.cms Retail Director detail report. Retrieved from https://m.economictimes.com/aditya-birlafashion-and-retail- 